$03 \mathrm{E00}$

8. Originator Remarks:

For approval.

3. From: (Originating Organization)
Packaging Engineering
6. Design Authority/ Design Agent/Cog.
Engr:
B. D. Flanagan

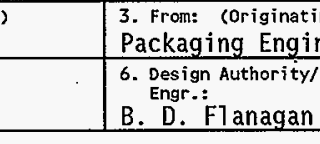

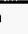

4. Related EDT No.:

7. Purchase Order No.:

NA

9. Equip./Component No.:

NA

10. System/Bldg./Facility:

NA

12. Major Assm. Dwg. No.:

NA

13. Permit/Permit Application No:: NA

14. Required Response Date:

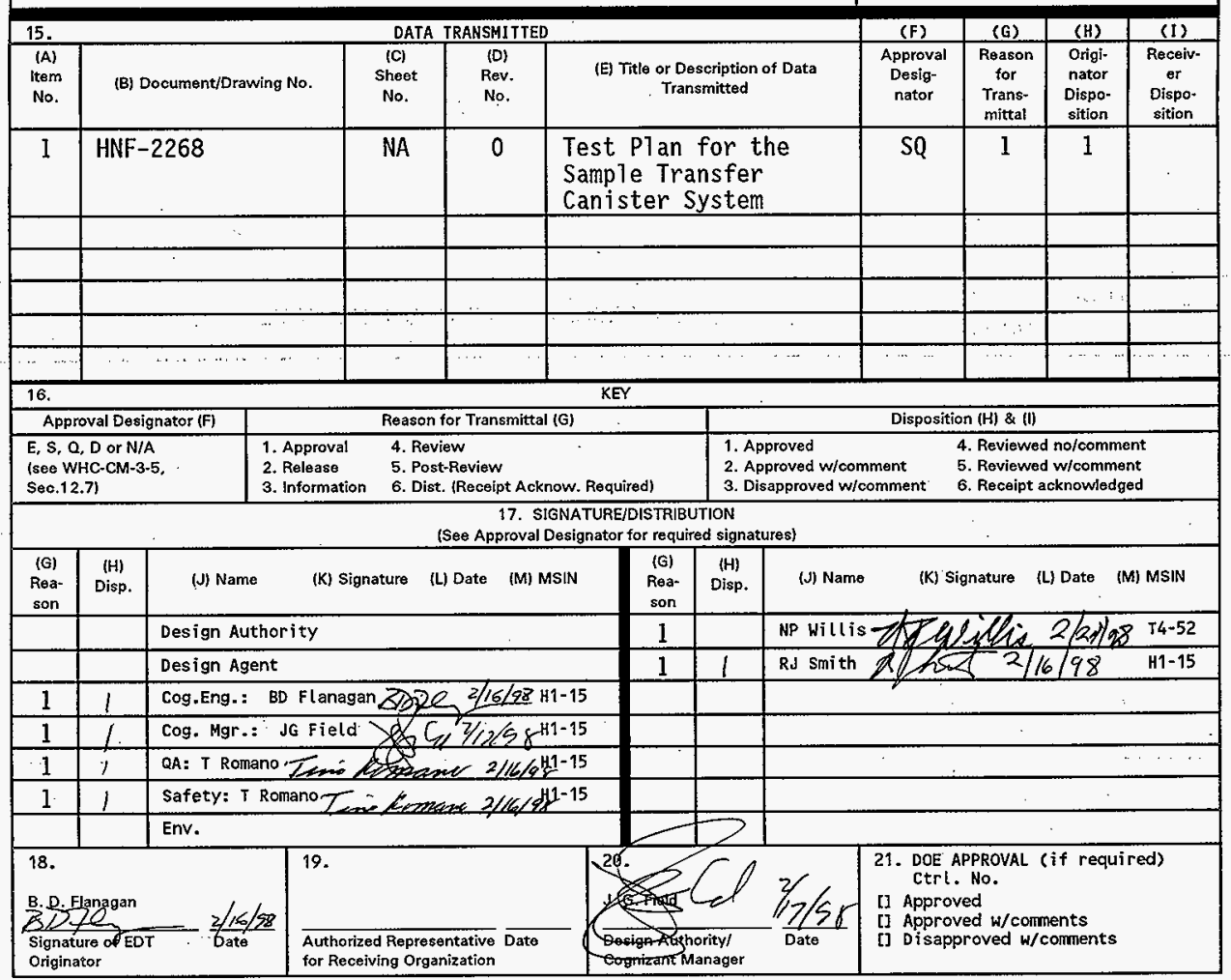




\section{Test Plan for the Sample Transfer Canister System}

\section{B. D. Flanagan}

Waste Management Federal Services, Inc.; Northwest Operations, Richland, WA 99352

U.S. Department of Energy Contract DE-AC06-96RL13200

EDT/ECN: EDT 621899 UC: 513

Org Code: 03E00

B\&R Code: YN010000
Charge Code: MDF3A

Total Pages: 13

Key Words: test plan, Sample Transfer Canister

Abstract: The Sample Transfer Canister will be used by the Waste Receiving and Processing Facility (WRAP) for the transport of small quantity liquid samples that meet the definition of a limited quantity radioactive material, and may also be corrosive and/or flammable. These samples will be 49 CFR 173.4, "Exception for small quantities."

TRADEMARK DISCLAIMER. Reference herein to any specific commercial product, process, or service by trade name, trademark, manufacturer, or otherwise, does not necessarily constitute or imply its endorsement, recomendation, or favoring by the United States Government or any agency thereof or its contractors or subcontractors.

Printed in the United States of America. To obtain copies of this document, contact: Document Control Services, P.O. Box 950, Mailstop H6-08, Richland WA 99352, Phone (509) 372-2420;

Fax (509) 376-4989.

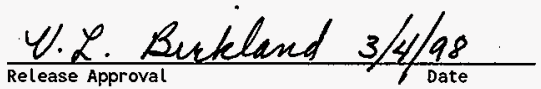

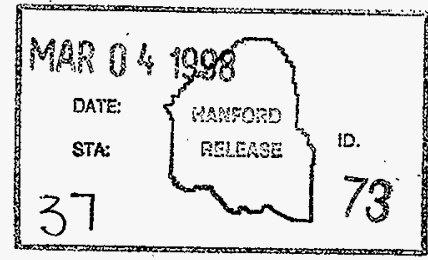

Release Stamp 
HNF-2268 Rev. O

\section{CONTENTS}

1.0 INTRODUCTION $\ldots \ldots \ldots \ldots \ldots \ldots \ldots \ldots \ldots \ldots \ldots \ldots \ldots \ldots \ldots \ldots \ldots$

2.0 PURPOSE/SCOPE $\ldots \ldots \ldots \ldots \ldots \ldots \ldots \ldots \ldots \ldots \ldots \ldots \ldots \ldots \ldots \ldots$

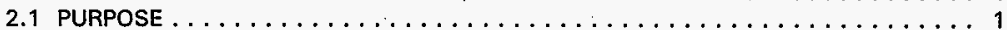

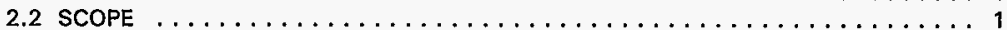

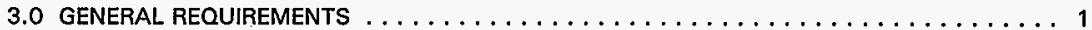

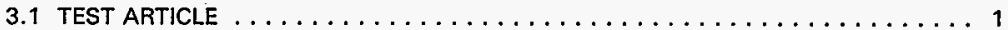

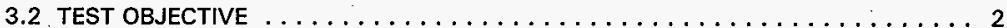

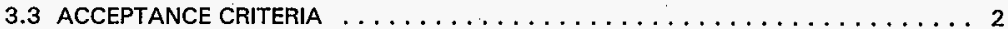

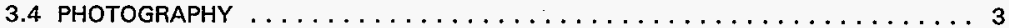

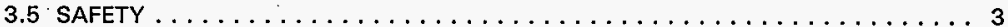

3.6 QUALITY ASSURANCE $\ldots \ldots \ldots \ldots \ldots \ldots \ldots \ldots \ldots \ldots \ldots \ldots$

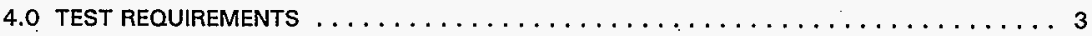

4.1 TEST FACILITY $\ldots \ldots \ldots \ldots \ldots \ldots \ldots \ldots \ldots \ldots \ldots \ldots \ldots \ldots \ldots$

4.2 REQUIRED TEST EQUIPMENT $\ldots \ldots \ldots \ldots \ldots \ldots \ldots \ldots \ldots \ldots \ldots \ldots \ldots$

4.3 TEST PERSONNEL $\ldots \ldots \ldots \ldots \ldots \ldots \ldots \ldots \ldots \ldots \ldots \ldots \ldots \ldots$

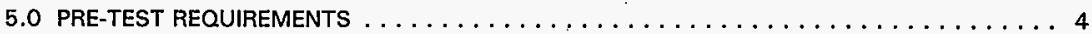

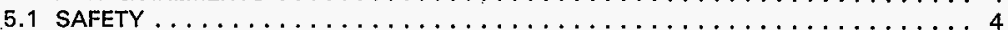

5.2 TEST PERSONNEL $\ldots \ldots \ldots \ldots \ldots \ldots \ldots \ldots \ldots \ldots \ldots \ldots \ldots \ldots \ldots$

5.3 FACILITIES, EQUIPMENT, AND MATERIALS $\ldots \ldots \ldots \ldots \ldots \ldots \ldots \ldots \ldots \ldots \ldots$

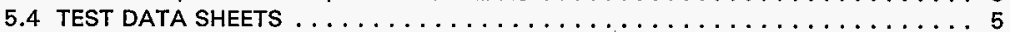

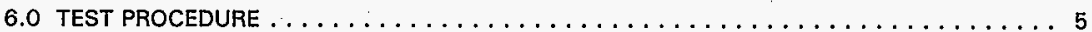

6.1 COMPRESSIVE TEST PROCEDURE $\ldots \ldots \ldots \ldots \ldots \ldots \ldots \ldots \ldots \ldots$

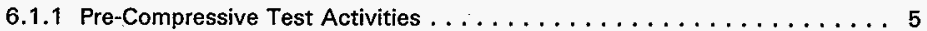

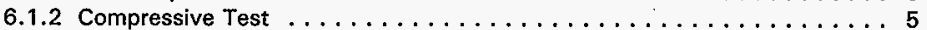

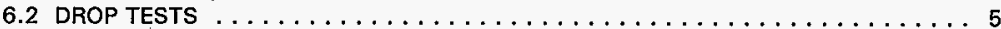

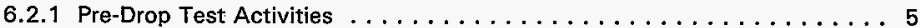

6.2 .2 Drop Tests . . . . . . . . . . . . . . . . . . . . 6

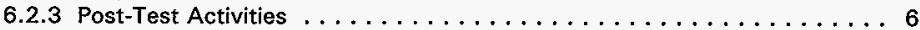

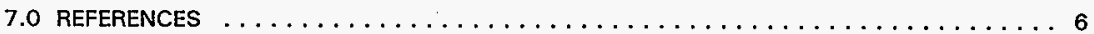

APPENDIX A. FORMS FOR TESTING $\ldots \ldots \ldots \ldots \ldots \ldots \ldots \ldots \ldots \ldots \ldots \ldots \ldots$

LIST OF TABLES

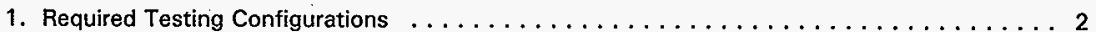

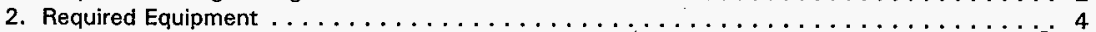

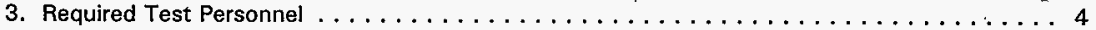


This page intentionally left blank. 
HNF-2268 Rev. 0

TEST PLAN FOR THE SAMPLE TRANSFER CANISTER SYSTEM

\subsection{INTRODUCTION}

The Sample Transfer Canister will be used by the Waste Receiving And Processing Facility (WRAP) for the transport of small quantity liquid samples that meet the definition of a limited quantity radioactive material, and may also be corrosive and/or flammable. These samples will be packaged and shipped in accordance with the U.S. Department of Transportation (DOT) regulation 49 CFR 173.4, "Exceptions for small quantities."

The Sample Transfer Canister is of a "French Can" design, intended to be mated with a glove box for loading/unloading. Transport will typically take place north of the Wye Barricade between WRAP and the 222-S Laboratory. The Sample Transfer Canister will be shipped in an insulated ice chest, but the ice chest will not be a part of the small quantity package during prototype testing.

\subsection{PURPOSE/SCOPE}

\subsection{PURPOSE}

The purpose of this test is to demonstrate that the Sample Transfer Canister wilt provide adequate protection to the inner receptacles as required under 49 CFR 173.4, "Exceptions for small quantities." The test procedure consists of a compressive load and drops in five required positions onto an unyielding surface to show the proven integrity of the canister system.

\subsection{SCOPE}

This test plan/procedure provides planning, pre-test, setup, testing, and post-testing guidelines and procedures for conducting the compression and drop tests for the Sample Transfer Canister. No radioactive or hazardous material are involved in this testing.

\subsection{GENERAL REQUIREMENTS}

\subsection{TEST ARTICLE}

The test article consists of the Sample Transfer Canister system. The system includes the metal Sample Transfer Canister, two $250 \mathrm{~mL}$ glass containers, bubble packing, and absorbent. To simulate the payload of the canister spilling, a water and red dye mixture will be used to determine if there are any leaks in the container. To ensure the payload simulant meets the maximum payload restriction of $30 \mathrm{~mL}$ or $30 \mathrm{~g}$ of material, approximately $125 \mathrm{~mL}$ of water and red dye per inner receptacle shall be used during the testing.

The Sample Transfer Canister is made of metal and is cylindrical in shape. The height is 10.5 in., the bottom diameter is 6.4 in., and the top $1.5 \mathrm{in.}$ of the canister is $9.0 \mathrm{in}$. in diameter. The lid is sealed with a gasket and closed by a drop and lock method against positive stops. 


\subsection{TEST OBJECTIVE}

The objective of this test is to determine whether the Sample Transfer Canister system can effectively meet the requirements stated in 49 CFR 173.4(a)/6). This will be accomplished by performing a compression test and five drop tests in the configurations described in Table 1 and evaluating any damage to the container and contents. Because the Sample Transfer Canister is cylindrical in shape the drop configurations meet the requirements as best as possible.

Table 1. Required Testing Configurations.

\begin{tabular}{|l|l|}
\hline Compression Test & $\begin{array}{l}\text { Place container system shall be placed on a hard flat surface. Stack } \\
350 \text { lb of lead bricks on top of container to simulate the stacking } \\
\text { requirements of } 49 \text { CFR } 178.606 \text { (c). }\end{array}$ \\
\hline Drop \#1 - Flat bottom & $\begin{array}{l}\text { The container system shall be raised } 71 \text { in. above the drop pad } \\
\text { (measured from the lowest point) with the bottom of the container } \\
\text { facing down. The container should be oriented such that the tine of } \\
\text { impact through the center of gravity (cg) is perpendicular to the floor } \\
\text { when released (flat drop). }\end{array}$ \\
\hline Drop \#2 - Flat top & $\begin{array}{l}\text { The container system shall be raised } 71 \text { in. above the drop pad with the } \\
\text { top (lid) of the container facing down. The container should be oriented } \\
\text { such that the line of impact through the cg is perpendicular to the floor } \\
\text { when released. }\end{array}$ \\
\hline Drop \#3 - Flat drop on side & $\begin{array}{l}\text { The container system shall be raised } 71 \text { in. above the drop pad } \\
\text { horizontally. The container shall be oriented such that at impact the } \\
\text { container hits squarely with the top and bottom impacting } \\
\text { simultaneously. }\end{array}$ \\
\hline Drop \#4 - Flat drop on side & $\begin{array}{l}\text { The container system shall follow the steps of drop \#3 but shall be } \\
\text { rotated to a new impact location. }\end{array}$ \\
\hline Drop \#5 - Corner drop & $\begin{array}{l}\text { The container system shall be raised } 71 \text { in. above the drop pad with the } \\
\text { top (lid) facing down. The container shall be oriented such that the line } \\
\text { of impact between the cg and the impacting edge is perpendicular to the } \\
\text { floor when released. }\end{array}$ \\
\hline
\end{tabular}

\subsection{ACCEPTANCE CRITERIA}

The acceptance criteria for the drop is that the inner receptacles survive without breakage or leakage and without a substantial reduction in the effectiveness of the package. To ensure that the inner receptacles do not leak or break, a mixture of water and red dye shall be placed within the receptacles.

A visual inspection of the exterior will be made of the Sample Transfer Container after each test. Any deflection of the canister shall be measured and photographed. After completion of the five drop tests the canister shall be opened and the contents inspected for breakage or leakage of the inner receptacles. 
HNF-2268 Rev. 0

\subsection{PHOTOGRAPHY}

The canister is to be photographed before each drop and after the drop to document any damage to the test article. Photographs should be concentrated around lid and areas of damage. Additional photographs will be taken during testing at the discretion of the cognizant engineer or a quality assurance (QA) representative.

The photography equipment will be supplied by the cognizant engineer.

\subsection{SAFETY}

The cognizant engineer shall coordinate with the Waste Management Federal Services, Inc., Northwest Operations (WMNW) safety engineer to review and establish safety requirements for the tests.

\subsection{QUALITY ASSURANCE}

Testing will be conducted under the WMNW quality assurance requirements as specified in EBU-QAP-001, Quality Assurance Procedures. Quality Assurance personnel will be notified of the proposed testing schedule and will witness the testing activities.

\subsection{TEST REQUIREMENTS}

\subsection{TEST FACILITY}

The test pad shall be composed of a hard unyielding surface such that all energy from the drop is applied to the container. A suitable test pad is located in the 300 Area of the Hanford Site.

\subsection{REQUIRED TEST EQUIPMENT}

Table 2 shows a partial list of equipment required for the drop tests. Equipment may be added or deleted from this list by the cognizant engineer, as required and documented. 
HNF-2268 Rev. 0

Table 2. Required Equipment.

\begin{tabular}{|l|l|}
\hline \multicolumn{1}{|c|}{ Item } & Responsibility \\
\hline Scale capable of measuring $50 \mathrm{lb}$ in 1 lb increments. - & \\
\hline Still camera and film & \\
\hline Rubber mallet & \\
\hline Standard screwdriver & \\
\hline Level & \\
\hline Pliers & \\
\hline Tape measure & \\
\hline Black marking pen & \\
\hline Safety glasses and hard hats for spectators & \\
\hline Caution tape & \\
\hline Broom & \\
\hline
\end{tabular}

\subsection{TEST PERSONNEL.}

The following personnel listed in Table 3 will be required for this test. Personnel involved in the testing are required to print their names, then initial and date next to their printed names.

Table 3. Required Test Personnel.

\begin{tabular}{|l|l|l|l|}
\hline \multicolumn{1}{|c|}{ Personnel } & Names (Print) & Initial & Date \\
\hline Cognizant Engineer: Bryan D. Flanagan & & & \\
\hline QA Rep.: Tino Romano & & & \\
\hline Technician: Juan M. Rodriguez & & & \\
\hline Technician: & & & \\
\hline
\end{tabular}

$\mathrm{QA}=$ Quality assurance.

The cognizant engineer and $Q A$ representative are required to witness all testing described in this procedure.

\subsection{PRE-TEST REQUIREMENTS}

\subsection{SAFETY}

All test operations shall be conducted in a safe manner. The cognizant engineer shall be responsible for the safety of personnel and equipment at the test site, for ensuring all witness and 
test support personnel are at assigned safe locations before lifting or dropping the test article, and for ensuring all personnel have required safety equipment (e.g., hard hats, eye protection).

\subsection{TEST PERSONNEL}

All test support personnel shall have received any required training prior to participating in the tests. All test operations shall be conducted by authorized personnel.

\subsection{FACILITIES, EQUIPMENT, AND MATERIALS}

Landlord concurrence for the use of the test facility shall be obtained by the cognizant engineer prior to any test activities.

The cognizant engineer shall schedule and arrange for the arrival of the Sample Transfer Canister system and all equipment needed during the testing.

\subsection{TEST DATA SHEETS}

All data sheets shall be witnessed and signed off by the cognizant engineer and the responsible $Q A$ representative after the completion of each test. All data sheets are located in Appendix A.

\subsection{TEST PROCEDURE}

\subsection{COMPRESSIVE TEST PROCEDURE}

\subsubsection{Pre-Compressive Test Activities}

The cognizant engineer shall complete a pre-test checklist (see Appendix A).

\subsubsection{Compressive Test}

The compressive test shall follow the test method of 49 CFR 178.606(c). The Sample Transfer Canister shall be placed on a flat hard surface (concrete floor) for a total minimum test period of 24 hours. The equivalent of $10 \mathrm{ft}$ of stacked canisters shall placed on the lid of the canister. The equivalent weight shall be determined during testing. The compressive test data sheet in Appendix A shall be completed.

\subsection{DROP TESTS}

\subsubsection{Pre-Drop Test Activities}

The cognizant engineer shall complete a pre-test checklist prior to the start of the drop tests (see Appendix A). 
HNF-2268 Rev. 0

\subsubsection{Drop Tests}

Each of the five drop tests shall follow the requirements described in 49 CFR 173.4(a)(6). The five drops include:
(A) One drop flat on the bottom;
(B) One drop flat on the top;
(C) One drop flat on the side;
(D) Another drop flat on the side at a different location that drop (C);
(E) One drop on the top (lid) edge of the canister.

Each drop shall be from a minimum height of $71 \mathrm{in.}$ onto the unyielding test pad. For each drop test the cognizant engineer shall complete a drop test data sheet from Appendix $A$.

\subsubsection{Post-Test Activities}

The cognizant engineer shall complete the post-test data sheet for the acceptance or failure of the acceptance criteria (see Appendix A).

\subsection{REFERENCES}

49 CFR 173.4, 1996, "Exceptions for small quantities," Code of Federal Regulations, as amended.

49 CFR 178.606, 1996, "Stacking Test," Code of Federal Regulations, as amended.

EBU-OAP-001, Quality Assurance Procedures, Waste Management Federal Services, Inc., Northwest Operations, Richland, Washington. 
APPENDIX A. FORMS FOR TESTING.

\section{Pre-Test Checklist}

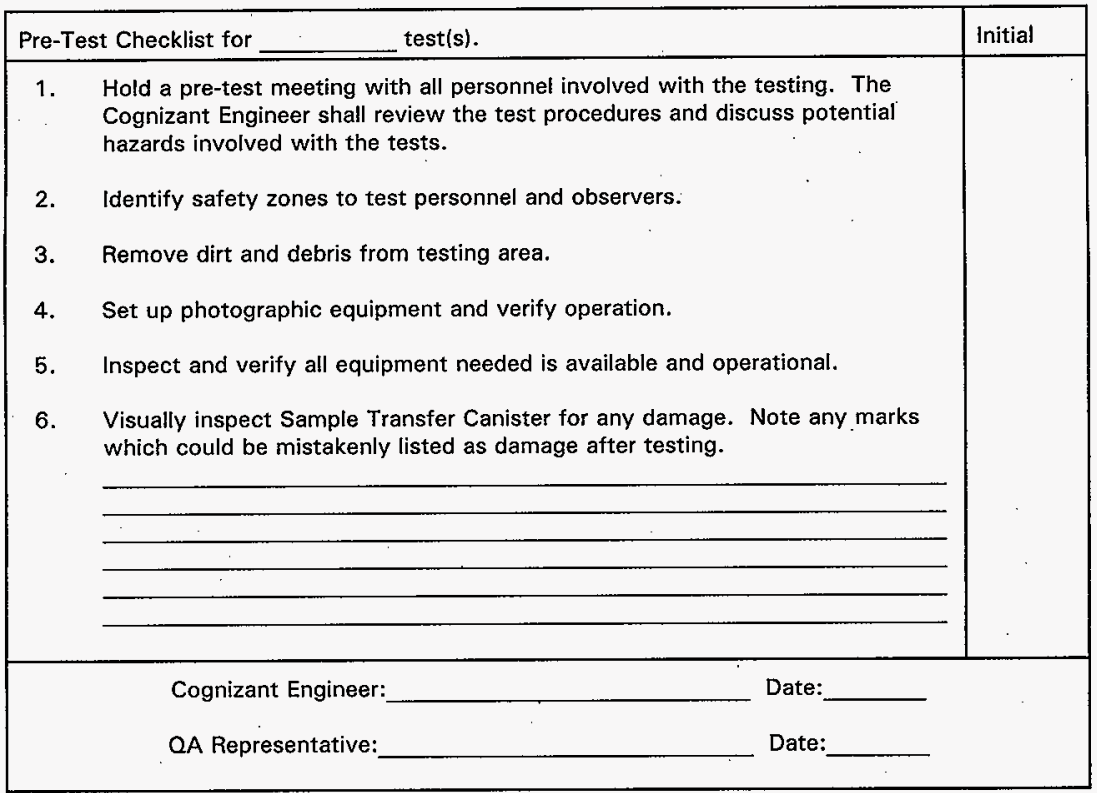




\section{Compression Test Data Sheet}

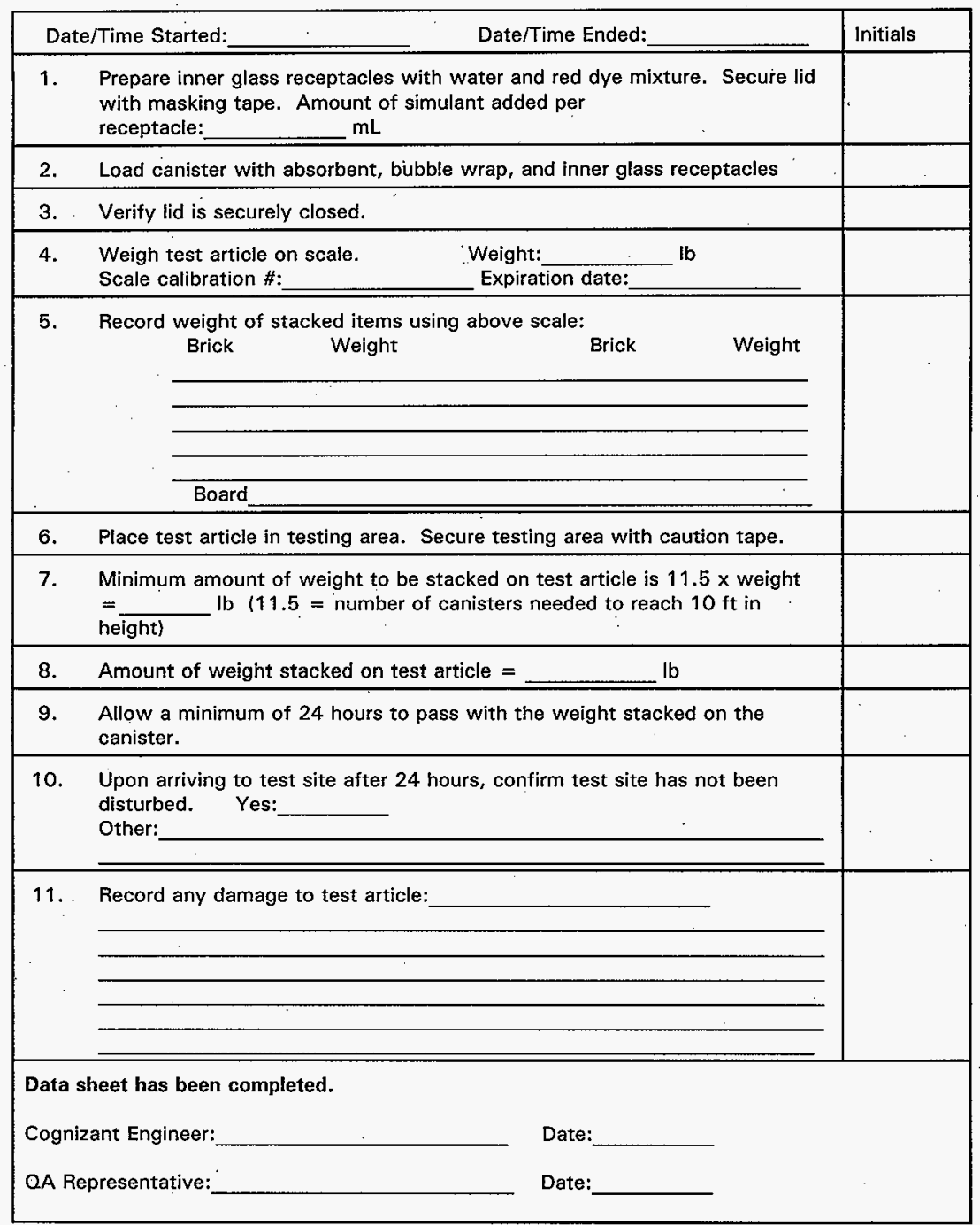


HNF-2268 Rev. 0

\section{Drop Test Data Sheet}

\begin{tabular}{|l|l|l|}
\hline Drop \#_ of $5 \quad$ Date/Time: & Initials \\
\hline 1. Location of \\
test:
\end{tabular}


HNF-2268 Rev. 0

\section{Post Test Data Sheet}

\begin{tabular}{|l|l|l|}
\hline Date/Time: & Initials \\
\hline 1. Verify all testing has been completed and all data sheets have been signed. & \\
\hline Open canister and evaluate the condition of the contents: & \\
\hline & & \\
\hline R. & \\
\hline Record any damage to the contents with the camera. \\
Cogt Data sheet has been completed. \\
OA Representative:
\end{tabular}


DISTRIBUTION SHEET

\begin{tabular}{|c|c|c|c|c|c|}
\hline \multirow{2}{*}{$\begin{array}{l}\text { To } \\
\text { Distribution }\end{array}$} & \multirow{2}{*}{\multicolumn{3}{|c|}{$\begin{array}{l}\text { From } \\
\text { Packaging Engineering }\end{array}$}} & \multicolumn{2}{|l|}{ Page 1 of 1} \\
\hline & & & & \multicolumn{2}{|c|}{ Date $02 / 17 / 98$} \\
\hline \multicolumn{4}{|c|}{ Project Title/Work Order } & \multicolumn{2}{|c|}{ EDT No. 621899} \\
\hline Test Plan for & Canister Sys & em (HNF-2 & 68) & \multicolumn{2}{|l|}{ ECN No. NA } \\
\hline \multicolumn{2}{|c|}{ Name } & $\begin{array}{c}\text { Text } \\
\text { With All } \\
\text { Attach. }\end{array}$ & Text Only & $\begin{array}{l}\text { Attach./ } \\
\text { Appendix } \\
\text { Only }\end{array}$ & $\begin{array}{l}\text { EDT/ECN } \\
\text { Only }\end{array}$ \\
\hline $\begin{array}{l}\text { J. G. Field } \\
\text { B. D. Flanagan } \\
\text { T. Romano } \\
\text { R. J. Smith } \\
\text { N. P. Willis } \\
\text { HNF-2268 File }\end{array}$ & $\begin{array}{l}H 1-15 \\
H 1-15 \\
H 1-15 \\
H 1-15 \\
T 4-52 \\
H 1-15\end{array}$ & $\begin{array}{l}x \\
x \\
x \\
x \\
x \\
x\end{array}$ & & & \\
\hline
\end{tabular}

